\title{
РЕЦЕПЦІЯ ГРЕЦЬКОЇ АНТИЧНОСТІ В СУЧАСНОМУ АНГЛІЙСЬКОМОВНОМУ РОМАНІ
}

\author{
Олександр Кеба
}

\author{
Доктор філологічних наук, професор, завідувач кафедри, \\ Кафедра германських мов і зарубіжної літератури, \\ Кам'янець-Подільський національний університет імені Івана Огієнка \\ 32300, м. Кам’янець-Подільський, вул. Івана Огієнка, 61, \\ e-mail: keba9591@gmail.com
}

\begin{abstract}
PЕФЕРАТ
Стаття присвячена дослідженню рецепції сюжетів і образів давньогрецької міфології і літератури в сучасному англійськомовному романі. Метою статті $є$ висвітлення основних тенденцій художньоестетичного осмислення античності та ії зв'язку з сучасністю у творах письменників Великої Британії, США, Канади та інших країн. Дослідницька методика грунтується на використанні історикогенетичного, структурно-функціонального, міфокритичного та компаративного методів. У результаті дослідження встановлено, що сучасні англійськомовні автори, представники різних національних літератур звертаються до античної доби з метою акцентування актуальних проблем сучасності. Античний дискурс у новітній англійськомовній літературі позначений складністю й багатоплановістю, характеризується амбівалентністю як власне рецепції античних претекстів, так і їх накладання на суперечливі тенденції сучасного людського буття. Наукова новизна дослідження полягає в тому, що порівняльно-типологічний аналіз романів «Пенелопіада» М. Етвуд, «Тягар» Дж. Вінтерсон, «Дім імен» К. Тойбіна, «Людське тавро» Ф. Рота, «Елізабет Костелло» Дж.М. Кутсі, «Таємна історія» Донни Тартт в інтертекстуальному аспекті досі не здійснювався. Матеріал і висновки статті можуть бути використані науковцями для подальшого дослідження місця античності в новітній літературі, особливостей ідейноструктурного функціонування античного інтертексту, а також при написанні кваліфікаційних робіт відповідної тематики у закладах вищої освіти.
\end{abstract}

Ключові слова: античність, сучасний англійськомовний роман, рецепція, міфологізація, інтертекстуальність.

\section{RECEPTION OF GREEK ANTIQUITY IN CONTEMPORARY ENGLISH-LANGUAGE NOVEL}

\section{Oleksandr Keba}

\author{
Doctor Habilitatus of Philology, Professor, Head of Department, \\ Foreign Literature and German Languages Department, \\ Kamianets-Podilskyi National Ivan Ohiienko University (UKRAINE), \\ 32300, Kamianets-Podilskyi, 61, Ivan Ohiienko str., \\ e-mail:keba9591@gmail.com
}

\begin{abstract}
The paper deals with the studying of reception of ancient Greek mythology and literature in contemporary English-language novels. The purpose of the study is to highlight the main tendencies of fictional transformation of antiquity and its connection with modernity in the works of British, American, Canadian etc. authors. Historical-genetic, mythopoetic, structural, functional and comparative methods are used for the research. The results of the studying show that the modern English-language writers, representatives of different national literatures, turn to the ancient times in order to emphasize actual problems of the present. Discourse of Greek antiquity in modern English-language literature marked by complexity and versatility. It is characterized by ambivalence as the very reception of ancient pretexts, as well as their imposition on the contradictory tendencies of contemporary life. Scientific novelty of the paper lies in the fact that a comparative analysis of the novels The
\end{abstract}


Penelopiad by M. Atwood, Weight by J. Winterson, House of Names by C. Tóibín, The Human Stain by Ph. Roth, Elizabeth Costello by J. M. Coetzee, The Secret History by Donna Tartt, Picture This by J. Heller has not been done before in the context of intertextuality. The conclusions of the paper can be used by scientists to determine the place of antiquity in contemporary literature, the features of structural functioning of ancient intertext, as well as in the writing of relevant qualification works in high school.

Key words: Greek antiquity, contemporary English-language novel, reception, mythologisation, intertextuality.

У європейській культурі були періоди різного ставлення до античності, від ідеалізації, властивої діячам епохи Відродження і класицизму, до скепсису стосовно пізнавального й художнього значення міфу, що було характерним для більшості просвітників XVIII століття, однак Еллада як колиска європейської цивілізації завжди залишалася в полі інтересу як учених, так і представників різних видів і жанрів мистецтва. У XX і XXI ст. цей інтерес не лише не вщухав, але набирав усе більших обертів. Навряд чи можна навіть перелічити ті твори новітньої світової літератури, в яких так чи інакше наявний зв'язок із культурою Стародавньої Греції. Як слушно зазначає М. С. Грабарь-Пассек, «кожна епоха зверталась до творів античності зі своїми власними цілями, шукала в них відповіді на запити сучасності, сприймала і зображала характери героїв давнини у відповідності з уявленнями і вимогами свого часу» [4, с. 5]. Iз сили-силенної творів ми обрали для нашої розвідки лише ті, автори яких акцентують насамперед на складності й неоднозначності античної доби, а також ті, в яких акцентованою є дискурсивна кореляція щодо сучасності. Об’єктом вибору слугували англійськомовні літератури, оскільки саме в них спостерігаємо найбільшу активність у художньо-естетичному осмисленні античної спадщини.

Твори сучасної літератури, які апелюють до античності, можна умовно поділити на такі групи: 1) сюжет розгортається безпосередньо в античну добу i, як правило, є варіацією відомого міфу або реальної історичної події; 2) події відбуваються в наш час, але представлені як аналог певного античного сюжету або коли певний античний претекст (міфема, міфологема, архетип тощо) формує ідейно-змістову концепцію твору. До першої групи відносимо такі романи, як «Надзвичайний посол» і «Подвійна мова» В. Голдінга, «Пенелопіада» М. Етвуд, «Тягар» Дж. Вінтерсон, «Дім імен» К. Тойбіна, «Мовчання дівчат» П. Баркер, «Пісня Ахілла» М. Міллер. До другої - романи «Кентавр» Дж. Апдайка, «Янгол світла» Дж.К. Оутс, «Людське тавро» Ф. Рота, «Елізабет Костелло» Дж. М. Кутсі, «Земля під іï ногами» С. Рушді, «Таємна історія» Д. Тартт. Окрему групу становлять твори, в яких багатоплановий сюжет включає події як античної доби, так і пізніших епох та сучасності, як-от «Падіння Трої» П. Акройда, «Уяви собі» Дж. Геллера, «Сон Сціпіона» Йєна Пірса та ін.

Звісно, що в межах відносно невеликої за обсягом розвідки немає можливості грунтовно проаналізувати всі названі вище твори, тому зупинимося в першу чергу на тих, які досі ще не ставали предметом детального критичного розгляду. При цьому завданням дослідження є виокремлення певних тенденцій новітнього художньо-естетичного осмислення античності, виявлення провідних 
поетико-наративних стратегій і типологічних закономірностей розвитку даного сегменту сучасного літературного процесу.

Роман відомої канадської письменниці Маргарет Етвуд «Пенелопіада. Міф про Пенелопу й Одіссея» (The Penelopiad: The Myth of Penelope and Odysseus, 2005) більшість критиків відносить до творів із яскраво вираженою феміністською спрямованістю, зокрема, за гінокритичною класифікацією Е. Шоуолтер, у фемальному варіанті жіночого письма [11]. Останній передбачає з'ясування насамперед специфіки жіночого голосу і погляду на світ. Безперечно, у самому тексті роману $є$ чимало підстав для такого типу інтерпретації, що й було доведено в низці критичних студій, що з'явилися щойно роман було опубліковано [див., напр.: 13]. У такому контексті цілком закономірним $\epsilon$ той факт, що романний образ Одіссея 3 «Пенелопіади» прочитувався у світлі феміністичної деконструкції, метою якої було викриття й розвінчання патріархальної парадигми всього давньогрецького світу. Але чи таким однозначно негативним $є$ Одіссей в художній інтерпретації Маргарет Етвуд?

Основне звинувачення, яке висувають проти Одіссея та його сина дванадцять служниць, визнаних Одіссеєм винними у зраді й повішаних за його наказом і за безпосередньої участі Телемака, це несправедливість, облуда, зневага і загалом упереджене ставлення до всього жіночого роду. Ситуація страти стає наскрізним мотивом роману, переростаючи у метафору страждань Жінки з вини Чоловіка. Певною уступкою авторки роману постмодерністським принципам гри наративом і реальністю $є$ те, що служниці звертаються до Одіссея «з висоти» нашого часу. Суд над чоловіком Пенелопи, на якому проти нього свідчать служниці, відбувається на початку XXI століття, що акцентовано у словах судді. Сама ж подія розповідання розгортається в межах загробного світу, й Пенелопі відомо все, що сталося «після» (симптоматичними є іiі слова про те, що «тут» часу просто немає: «it's hard to keep track of time here» [1].

Пенелопа не може не погодитися 3 висунутими проти Одіссея звинуваченнями, хоча й намагається пояснити, що все сталося через збіг обставин, які їй самій не вдалося виправити. Натомість ії ставлення до Одіссея позбавлене однозначності й категоричності. Враховуючи поширені як у давньогрецькій міфології та літературі стереотипні уявлення про «Одіссеягероя», так і наступні художньо-естетичні інтерпретації цього архетипного образу (аж до Джойсового «Улісса»), Пенелопа стверджує його амбівалентну сутність. Вона згадує різноманітні епізоди їхнього подружнього життя від моменту змагання Одіссея за право бути нареченим доньки спартанського царя Ікарія й у кожному віднаходить мудрість і винахідливість ітакського царя, хоча ці якості часто межують із шахрайством, каверзами й обманами. Пенелопа визнає своєрідну універсальність Одіссея як людини (про що говорив і Джеймс Джойс, пояснюючи свій вибір людини-взірця для «негероїчної» сучасності). Він - хоробрий і сильний воїн, вправний і мужній мореплавець, вольовий i дипломатичний правитель, геній комунікабельності й компромісу, блискучий розповідач і уважний співрозмовник, відданий сім'янин, чоловік і батько (поширені чутки про «зради» чоловіка дружина схильна виправдовувати 
ситуаціями «причарованості»). Перейнявшись від самого весілля повагою і любов'ю до Одіссея, Пенелопа зберігає свої почуття на довгі роки, про що сама говорить, перебуваючи в «чертогах Аїда».

«Пенелопіада» має доволі вигадливу наративну структуру, певним чином уподібнену до структури давньогрецької трагедії. Розповідь ведеться від імені Пенелопи, однак її голос постійно переривається хором дванадцяти служниць, стилістика звучання якого кожного разу змінюється: від античних ламентацій до сучасних рок-н-рольних ритмів. При цьому Пенелопа виступає апологетом Одіссея, стверджуючи, що той уже спокутував свою провину, очистився від гріха, піднісши за них до небес молитви. Однак служниці знову й знову з'являються на сцені, щоб невпинно нагадувати про вічний гріх Чоловіка перед Жінкою.

Отже, образ Одіссея в «Пенелопіаді» Маргарет Етвуд позначений очевидною амбівалентністю й об'єктивно не вписується у суто феміністську деконструкцію так званих патріархально-маскулінних цінностей.

Роман сучасної англійської письменниці Джанет Вінтерсон «Тягар. Міф про Атласа і Геракла» (Weight. The Myth of Atlas and Heracles) був опублікований 2005 року як твір у резонансній серії «Міфи« видавництва «Canongate U.S.». Це надто специфічний переказ одинадцятого подвигу Геракла, що перемежається 3 космогонією зародження й геологічної еволюції життя на Землі, світоглядними уявленнями античної і сучасної людини про Всесвіт, сутність і призначення людини, а також рефлексіями нараторки щодо власної екзистенції і життєвого тягаря, що випав на її долю. 3-поміж численних джерел, звідки авторка могла черпати матеріал для своєї праці, найбільш вірогідним видається класична праця Роберта Грейвса «Міфи Стародавньої Греції» [5].

У центр романного сюжету поставлено історію обману Атласа Гераклом, який попросив його добути яблука із саду Гесперид. Коли Атлас повернувся із яблуками й уже вирішив не приймати на себе земний тягар, Геракл умовив його лише на хвильку знову взяти Землю на плечі, щоб нібито підкласти на плечі баранячу підстилку, а потім просто покинув його, пішовши геть із отриманим трофеєм. У процесі розгортання даного сюжету Дж. Вінтерсон наділяє персонажів свого твору осучасненими прагненнями та рефлексіями, протилежними характерами і світоглядно-екзистенціальними позиціями.

Атлас у романі письменниці виступає не лише символом терпіння, стійкості, відповідальності, а й показаний як людина, що переймається екзистенціальними страхами, тривогами, страждає через душевні переживання, невпевненість у собі, самотність і відчуження. Його світосприйняття має підкреслено тілесний вимір (що загалом характерне для художньо-естетичної позиції письменниці; згадаймо іiі найвідоміший роман «Written on the Body»): «This is the body, and my body is the world in little. I'm the Kosmos - the all that there is, and at the same time I was never more outside, never more than nothing. Nothing bounded by nothing. Nothing has an unlikely property. It is heavy. ...» [16]. Показово, що авторка вживає тут слово грецького походження - Kosmos, що означає як порядок, устрій, так і всесвітню красу. 
Натомість деміфологізація образу Геракла здійснюється в романі у прямо протилежному напрямі. Від найславетнішого 3 міфологічних героїв Стародавньої Греції залишилася хіба лише сила й відвага, та й та скоріше схожа на безрозсудність; він показаний людиною із примітивними, щоб не сказати суто тваринними, прагненнями й інстинктами. Геракл уражений різноманітними психосоматичними комплексами: самолюбством, марнославством, манією величі. Йому властива непереборна тяга до нічим не обмеженої насолоди й задоволення. Він і висловлюється про це не просто прямо, а вкрай грубо й вульгарно. Найбільше, чого боїться Геракл, - це втратити свою виплекану свободу, але якраз цього в його житті й немає; відтак він перетворюється на заручника власних бажань і комплексів.

Згідно $з$ класифікацією Ярослава Поліщука [9, с. 38], реалізований у романі тип ставлення до класичного міфу та стратегія його художньо-естетичної трансформації може бути інтерпретований як деміфологізація, тобто радикальне переосмислення зафіксованої у конкретному міфі традиції та надання йому почасти протилежного щодо первісного інваріанту змісту. Саме такому переосмисленню й піддається добре знана освіченому читачеві історія Атласа і Геракла.

Цікаво, що в романі має місце своєрідне палімпсестне накладання античного і біблійного міфу. Наприклад, коли Гера пояснює Атласові, що станеться 3 людиною, яка отримає яблуко з саду Гесперид, ії слова явно нагадують міф про біблійний сад: «Anyone who plucks these apples will be like the gods, knowing past and future as though they were today...» [16]. У подібному ж ключі інтерпретується й історія з братом Атласа Прометеєм, який несе свій тягар нескінчену муку покарання за наданий людям дар володіння вогнем. При цьому його подвиг також деміфологізується, що скептично констатує Гера: «Everything that man invents he soon turns to his own destruction. Your brother Prometheus stole fire and what did men do with that gift? They learned to burn each other's crops and houses. Chiron taught you medicine and what did you learn to make? Poisons. Ares gave you weapons, and what did you do with them but kill each other?» [16]. I загалом дароване людям щастя жити на Землі вони перетворюють на тягар. Саме життя інтерпретується в романі амбівалентно: це і дар, і тягар одночасно.

Кожна людина, стверджується в романі, сама створює і несе на собі свій світ: «It's on my back now, vast and expanding. I hardly recognize it. I love it. I hate it. It's not me, it's itself. Where am I in the world I have made? Where in the world am I?» [16].

Важливе значення у художній структурі роману займають паралелі між античністю і сьогоденням, між макровсесвітом космічних траєкторій і мікровсесвітом людського буття. Реалізуються вони за допомогою розгорнутих включень прямого голосу нараторки (максимально наближеної до самої авторки), що мають форму філософської есеїстики 3 акцентованим автобіографічним контекстом. Так, осягнення закономірностей руху планет Сонячної системи, історії земної еволюції, меж людського існування здійснюється крізь призму наративного дискурсу, «розказування історій»: «What limits? There are none. The story moves at the speed of light, and like light, the story is 
curved. There are no straight lines. The lines that smooth across the page, deceive. Straightforward is not the geometry of space. In space, nothing tends directly; matter and matter of fact both warp under light. If only I understood that the globe itself, complete, perfect, unique, is a story. Science is a story. History is a story. These are the stories we tell ourselves to make ourselves come true...» [16].

Таким чином, Джанет Вінтерсон, як i Маргарет Етвуд, очевидно деміфологізує низку традиційних сюжетів і образів, осучаснює їх за рахунок включення відомих персонажів давньогрецького міфу у контекст вічних i водночас актуальних для сьогодення загальнолюдських проблем, універсалізуючи концепти долі, обов'язку, відповідальності, вибору і свободи, надаючи їм виразного екзистенціального змісту.

Багато в чому подібним до творів М. Етвуд і Дж. Вінтерсон є роман сучасного ірландського письменника Колма Тойбіна «Дім імен» (House of Names, 2017). Сюжет його $є$ свого роду компіляцією різних джерел історії про вбивство Агамемнона Клітемнестрою та наслідків цієї події. Автор у післямові вказує на ці джерела, не виокремлюючи якийсь один як центральний: «Орестея» Есхіла, «Електра» Софокла, «Електра», «Орест», «Іфігенія в Авліді» Евріпіда [15, р. 270]. На відміну від М. Етвуд і Дж. Вінтерсон, К. Тойбін не вдається до деміфологізації відомого сюжету, не осучаснює його експліцитно, a, скоріше, працює у межах стратегії міфологізування [8, с. 10], домислюючи і дописуючи певні прогалини в давньогрецьких варіантах сюжету. При цьому в окремих частинах він різко психологізує характери, а в інших вдається до предметно-подієвої деталізації. Як відомо, Агамемнон перед походом на Трою приносить у жертву богам задля переміни вітру і майбутньої перемоги свою молодшу дочку Іфігенію. Цей зав'язковий епізод усієї історії в романі передається через сприйняття Клітемнестри, яка не може пробачити чоловікові й тому замислює вбивство Агамемнона після повернення 3-під стін Трої 3 допомогою його двоюрідного брата Егіста, на той час ув'язненого в якості заручника в підземеллі Агамемнонового палацу.

Роман складається 3 шести нерівномірних за обсягом частин, кожна 3 яких написана в іншій наративній перспективі. Перша, найбільша, має назву «Клітемнестра». Організована від першої особи, розповідь у цій частині сконцентрована на мотивах материнського страждання, жіночої образи i непереборної жаги помсти. Клітемнестра виправдовує свій «праведний гнів» чоловічою жорстокістю, обманом i немилосердністю. П'ята частина, найкоротша, також називається «Клітемнестра», й у ній розповідь ведеться від імені героїні, яка вже перебуває у потойбічному світі й тінню-привидом приходить у свій колишній дім, щоб побачити сина, який убив ііі. Друга, четверта і шоста частина мають однакову назву «Орест». Вони різняться за обсягом і написані від третьої особи. Найбільшою $є$ друга частина, в якій детально розповідається про перебування Ореста за межами столиці царства, спочатку у таємній в'язниці в горах разом із іншими хлопчиками, яких Егіст вивіз із міста як заручників, а потім п'ять років у хижі якоїсь старої. Третя частина написана від імені Електри, яка, знаючи про змову матері з Егістом та вбивство обожнюваного нею батька (згадується комплекс Електри, сформу- 
льований Фройдом!), виношує плани помсти і врешті-решт здійснює їх, підбиваючи Ореста до вбивства матері.

На перший погляд, Тойбін просто переказує міф, доповнюючи його деталями із п'єс давньогрецьких драматургів й експлуатуючи все ті ж проблеми смертельних образ і помсти. Однак насправді роман по-сучасному концептуальний. Він не лише акцентує проблему коловоротності зла й насильства, але й піднімає такі проблеми, як відносність істини й знання про людину, пам'яті й забуття, богопокинутість світу й трагічна «самостійність» людини. У романі вдало реалізуються новітні наративні та дискурсивні стратегії - точка зору i перспектива, поліфонія і ненадійна нарація, слово і мовчання, голос і тиша, ім'я і сутність тощо. Істотно й те, що твір відповідає й на певні феміністичні запити. Те, що «жіночі» частини роману написані від першої особи, а частини під назвою «Орест» від третьої особи, є також концептуальним. Орест не має свого голосу і не має власної позиції. Він увесь час виявляється маріонеткою в чужих руках. Спочатку - батькових, потім - Егістових, Леандрових, Електрових, йому не довіряють ні рідні, ні старійшини, ні Леандр, якого він уважає своїм найближчим товаришем. Вбивство матері Орест виправдовує тим, що цим відновлює честь свого батька і свого роду, але насправді це виправдання $\epsilon$ самообманом й ілюзією. Навіть те, що роман завершується народженням дитини Іанти, сестри Леандра, з якою має одружитися Орест, не будучи батьком цієї дитини (іі згвалтували п'ятеро спільників Егіста), видається симптоматичним, адже кровний рід його тим самим остаточно перерветься.

Варто зауважити й на тому, що при всій повній зануреності автора в античну добу й відсутності в тексті роману прямих алюзій на сучасність, все ж можна говорити про імпліцитні авторські інтенції виходу за межі античного часопростору. Так, окремі деталі сюжетного дійства роману не вповні відповідають грецькому топосу. Зокрема, географічні й кліматичні реалії твору скоріше нагадують не південну, а північну Свропу, не грецькі, а британські острови, а масові вбивства супротивників Агамемнона й Егіста перегукуються 3 насильством у Північній Ірландії 1970-х рр., яку дуже болісно сприймав автор роману і неодноразово говорив про це у своїх інтерв'ю [див., зокрема: 14].

Автори романів другої групи у процесі формування ідейно-художніх стратегій кореляції сучасності й античності, як правило, вдаються до системної інтертекстуалізації тексту. Так, у романі Філіпа Рота «Людське тавро» (The Human Stain, 2000) першим і найбільш очевидним чинником включення античного інтертексту $є$ професійна діяльність головного героя Коулмена Сілка, який присвятив себе студіюванню й викладанню античної художньої словесності в одному з невеликих американських університетів у Новій Англії. Фактично все життя протагоніста стало боротьбою із долею, «прописаною» йому як представникові афро-американської спільноти в середині XX століття. Він піднявся на вищі щаблі соціальної (а згодом і науково-академічної) ієрархії, відмовившись від своєї раси.

Наратор першого рівня у творі, письменник Натан Цукерман, намагається інтерпретувати життя свого товариша і персонажа писаної ним історії крізь призму концепції життя як самотворення. Водночас наратор постійно 
наштовхується на нездоланні перешкоди в осягненні закономірностей людської екзистенції та долі Коулмена Сілка: від зречення родини - вчинку, що визначив все його подальше життя, до зв'язку колишнього професора, декана коледжу 3 прибиральницею Фауні Фарлі, що спричинило їх трагічну загибель.

Роман має складну сюжетно-композиційну i наративну структуру. Нелінійне розгортання розповіді, численні фрагментарно-ретроспективні елементи, метатекстуальні вторгнення наратора порушують причинно-наслідкові кореляти, традиційні для соціального роману і роману кар'єри, до якого цей твір можна віднести з відповідними застереженнями. Водночас вивчення життя Коулмена Сілка приводить Натана Цукермана до парадоксального висновку про принципову «невизначеність» цієї історії: «Now that I knew everything, it was as though I knew nothing» (далі роман цитуємо за: [10]). У цьому сенсі показовими виглядають гіпотетичні констатації на кшталт «припускаючи» («assuming»), що тричі повторюються впродовж однієї з останніх рефлексій наратора.

На недетерміністську концепцію твору «працюють» і його метатекстуальні елементи: наратор одночасно розмірковує і над історією Коулмена Сілка, і над самим процесом написання книги про нього, уподібнюючи життя текстові (відомий постмодерністський постулат): «Your book was your life...».

У свою чергу метатекст роману нерозривно пов'язаний із його інтертекстом, а концепція життя Коулмена Сілка як «трагічного героя« («in behalf of his heroic conception of his life») ефективно підтримується ремінісценціями та алюзіями з античної міфології та літератури.

Цілком органічно виглядають у романі часто згадувані імена богів і героїв давньогрецької міфології, авторів та персонажів епічних та драматичних творів античної доби, політичних діячів та філософів. Вони постійно цитуються, певним чином інтерпретуються, а ті чи інші реалії та ситуації сьогодення майже позасвідомо фіксуються героєм у поняттях і образах античної культури, як-от: «That was all of the chorus Coleman overheard...». Це - «верхній», експліцитний рівень античного інтертексту. Він є функціональним елементом «прямої дії» і доповнюється імпліцитними формами зв'язку роману з античними претекстами.

На концептуальному рівні відсилання до міфологічних і літературних першоджерел античності набувають значущості насамперед щодо тієї ідеї життя, яку сформулював для себе Коулмен Сілк і якої неухильно дотримувався упродовж більше п'ятдесяти років. Особливо часто автор звертається до Софокла і його трагедії «Цар Едіп», епіграфом з якої, власне, й відкривається роман. Молодий Коулмен, назвавшись при вступі до Військово-Морських Сил США білим (точніше, євреєм, що найбільше відповідало його зовнішності), приймає рішення «взяти майбутнє в свої руки замість того, щоб підкоритися долі». При цьому він трактує свій вибір не просто на користь якоїсь іншої спільноти і прагне понад усе бути не тільки не чорним, а навіть і не білим, а лише бути самим собою і вільним («to be free: not black, not even white - just on his own and free»). Сілк зрікся своєї раси задля того, аби втілити у своєму житті 
ідею очищеного «Я», стати над расами й оманами, над будь-якими проявами «Ми» $\mathrm{i}$ «Вони».

Метою Сілка було зробити так, щоб його долю зумовлювали не впливи ворожого зовнішнього світу, а його особиста воля. Майбутній професор класичної філології, ще не осягнувши повною мірою, тільки підступаючи до усвідомлення трагічних обертонів долі в ii античному вимірі, на відміну від свого античного прототипу, вступає у двобій із тим, що йому наперед визначено соціальним статусом. Він хоче стати іншою істотою, заново народитися i жити своїм особистим проєктом, «помірятися силами зі світом».

Доля, неминучість, випадковість, непередбачуваність - ці категорії, якими жили для Сілка античні персонажі, стають складовими його власного екзистенційного буття. Студіювання античності дає йому розуміння парадоксальних поворотів долі: «how easily life can be one thing rather than another and how accidentally a destiny is made... on the other hand, how accidental fate may seem when things can never turn out other than they do».

Натан Цукерман напружено розмірковує над долею Коулмена Сілка i доходить висновку, що той неусвідомлено прагнув значного більшого, ніж просто досягти свободи. Той, хто здатен зректися найдорожчого для нього любові матері і власної любові до матері - той хоче довести собі, що він справді здатен на таке. «Тут більше ніж бажання насолодитися свободою. Тут щось із «Іліади» 3 iї жорстокістю, з улюбленої книжки Коулмена про хижий дух у людині» (ravening spirit of man). Так через античну ремінісценцію вноситься додатковий штрих до назви роману: «Людське тавро» - це не лише одвічний людський гріх непокори й гордині, не лише пристрасті, що пожирають людину, а й те, що спричиняється ними, - егоцентризм, свавілля, гнів, жорстокість, хижацтво. Знаменитий американський індивідуалізм очевидно набуває в романі амбівалентного смислу.

Зв’язок героя роману 3 античною міфологією акцентується й на рівні предметно-художньої зображальності, навіть в елементах портретування. Так, молодий Коулмен Сілк уявляється Натанові Цукерману «козлоногим Паном», коли той розповідає йому про свої студентські роки, захоплення античністю й водночас енергійну включеність у бурхливу коловерть американського повоєнного життя: «а snub-nosed, goat-footed Pan».

За життя Коулмена Сілка його найбільшим антагоністом у родині був син Марк, який жодною мірою не приймав «антично-язичницьких» пристрастей свого батька і протиставив їм біблійну мораль та виваженість життєвих цінностей (невипадково вже у дорослому віці Марк намагається ствердитися на літературному поприщі як автор творів розповідного жанру на біблійні сюжети).

Цікаво, що Натан Цукерман, повністю засуджуючи Марка за небажання зрозуміти батька, сам також людськими пристрастями пояснює затаврованість людей. Вираз «людське тавро» наратор приписує Фауні Фарлі, хоча ¥і1 світосприйняття змодельоване ним на основі розповідей Коулмена Сілка. Стверджуючи неминучу «заплямованість» людини, наратор знову ж таки розкриває іï за допомогою античної міфології, подаючи своє розуміння сучасної 
живучості верховного грецького бога: «entangled in adventure, vividly expressive, capricious, sensual, exuberantly wedded to his own rich existence...»

Коулмен Сілк називає Фауні «Сленою Троянською», на що та іронічно відгукується «Єлена Нізвідкільна», «Єлена Ніяка» («Helen of Nowhere. Helen of Nothing»). Ще одне ім'я, яке Фауні отримала від Сілка, також має античне походження. Волюптас - донька Амура і Психеї, римська богиня чуттєвої насолоди. Нарешті, третє «античне» ім'я - Галатея - дає Фауні Натан Цукерман, коли спостерігає за нею і Коулменом під час відвідування концерту класичної музики: «Under the auspices of Aphrodite, in the guise of Pygmalion, and in the environs of Tanglewood, was the retired classics professor now bringing recalcitrant, transgressive Faunia to life as a tastefully civilized Galatea?».

Натомість сам Коулмен Сілк не бажає уподібнюватися до трагічного персонажа на його фатальному шляху. Він декілька разів згадує Філоктета, персонажа «Іліади» і героя однойменної трагедії Софокла. Філоктет довго жив у повній самоті на острові Лемнос, тому що рана від зміїного укусу породжувала нестерпний сморід. Таке виключення 3 життя жодною мірою не влаштовує Сілка, і він робить усе, щоб подолати накладену на нього долею неминучість.

Крім Коулмена Сілка, у романі є ще один персонаж, деталі й обставини життя якого прочитуються крізь призму античного інтертексту. Це - Дельфіна Ру, наступник декана Сілка на цій посаді, інтелектуалка, апологет новітніх наукових стратегій інтерпретації літературних текстів, зокрема у феміністичному ключі, випускниця найпрестижніших навчальних закладів Європи (Еколь Нормаль) і США (Єльський університет). Навіть приймаючи свого часу iï на роботу до Афіни-коледжу, декан Сілк відчуває штучну амбітність та поверховість ії життєвої і наукової позиції. Очевидно, й у двозначності ії грецького імені («дельфін» з давньогрецької можна перекласти і як вигнутість, і як матка) відбивається загальне іронічно-зверхнє ставлення до неї як протагоніста, так і наратора. Додатковим штрихом до непривабливого змалювання Дельфіни є їі перстень із вирізьбленим на ньому зображенням Данаї, яка приймає Зевса у вигляді золотого дощу. Врешті-решт саме француженка Дельфіна-Даная стане своєрідним рупором американської благопристойності й зробить усе, щоб дискредитувати Коулмена Сілка в очах громадськості й академічної спільноти.

Як бачимо, античний інтертекст у романі Ф. Рота «Людське тавро» має цілу низку художньо-естетичних вимірів, слугуючи осягненню глибинних закономірностей людського буття, одвічної боротьби волі й долі, «Я» $\mathrm{i}$ «Ми», неминучих амбівалентних суперечностей у здійсненні амбітно-величних життєвих проєктів.

Роман Дж. М. Кутсі «Елізабет Костелло» (Elizabeth Costello, 2003) визнається одним із найбільш глибоких і багатопланових творів письменника [6, p. 19]. Не в останню чергу такий статус роману обумовлюється щільним насиченням тексту різноманітними формами інтертексту, зокрема, пов'язаними 3 протиставленням античного i християнського ідеалів. Безпосередньою підставою органічного включення інтертексту в художню структуру є те, що 
головна героїня твору, ім'я якої, власне, й дає йому назву, є письменницею. Автор наділяє Елізабет Костелло непростою творчою біографією і активною життєвою позицією, робить добре відомою в літературному й академічному світі: їй присуджують літературні премії, запрошують в університети для читання лекцій тощо.

Дев'ять «уроків» (так автором означені структурні частини роману) Елізабет Костелло - це, по суті, різні аспекти ії життєвої і митецької філософії. Ключовим у романі $є$ «урок» під назвою «Гуманітарні науки в Африці». Саме в Африці мешкає однокровна сестра Елізабет на ім'я Бланш, яка керує медичним центром i водночас виконує значну роботу як представниця католицької місіонерської місії. Елізабет Костелло приїздить до Африки, аби взяти участь у церемонії присудження сестрі почесного докторського ступеня в місцевому університеті. Під час церемонії Бланш присвятила свій виступ протиставленню світської гуманітарної науки, яка, на іiі думку, ізолювалася в інтерпретації текстів і відійшла від первісного призначення гуманітаристики - наближення людини до Бога, християнському вченню. Після неоднозначного сприйнятого виступу й доволі різкого обміну думками під час вечірки сестри продовжують дискусію удвох. Елізабет відстоює необхідність залучення африканського населення, якому Бланш пропонує лише страждаючого Христа, до здобутків європейської культури в ії первісному, античному ідеалі гармонії.

Бланш відкидає античні цінності, уважаючи їх оманливими, i протиставляє їм ідеал Христа. При цьому вона ототожнює так званий аполлонізм 3 раціоналізмом і стверджує, що Елізабет «поставила не на тих греків»: «Orpheus instead of Apollo. The ecstatic instead of the rational. Someone who changes form, changes colour, according to his surroundings. Someone who can die but then come back. A chameleon. A phoenix. Someone who appeals to women. Because it is women who live closest to the ground. Someone who moves among the people, whom they can touch - put their hand into the side of, feel the wound, smell the blood...» [2]. Відтак Орфей у їі пасажі виступає свого роду предтечею Ісуса Христа.

Насправді у звинуваченнях Бланш мало справедливості - вона й не читала романів сестри, про які сказано, зокрема в наративній перспективі іiі сина, професора математики, що в них надто багато пристрасті. Крім того, для Елізабет Костелло очевидною $є$ міфологічно-ірраціональна природа мистецтва. Вона сама звинувачує західну цивілізацію в раціоналістичних ілюзіях (особливо в частині-«уроці» «Життя тварин»): «Of course reason will validate reason as the first principle of the universe - what else should it do? Dethrone itself? Reasoning systems, as systems of totality, do not have that power. If there were a position from which reason could attack and dethrone itself, reason would already have occupied that position; otherwise it would not be total...» [2]. Ригоризму Бланш, ii розумінню гуманізму і гуманітарних наук Елізабет Костелло протиставляє «гуманність» як людське милосердя, співчуття, емпатію і співпереживання болю іншого.

Дискусія між сестрами має доволі неоднозначний зміст ще й через те, що протиставлення Аполлона і Діоніса, акцентоване Бланш, насправді не є таким 
простим. Наразі добре відомо, що для Ніцше, який трактатом «Народження трагедії з духу музики» «повернув» європейській культурі Аполлона й Діоніса, це протиставлення було пов'язане не так із класичною еллінською культурою, як із відкриттям докласичної, архаїчної Греції, в якій оприявнилися першовитоки буття, що трансформувалися згодом в архетипи Аполлона й Діоніса, а ще пізніше в антитезу Діоніс - Сократ, а далі у контроверзу Діоніс - Христос [див.: 7].

Якщо в романі Кутсі дискусія про аполлонівське й діонісійське є важливою, але не єдиною складовою багатопланового твору, то в романі Донни Тартт «Тасмна історія» (The Secret History, 1992) [12] названі концепти виконують системотвірну роль. Головні герої цього твору, п'ятеро обдарованих студентів американського коледжу, наполегливо студіюють античність. За інспірацією свого наставника вони настільки заглиблюються у феномен діонісійства, що прагнуть в буквальному сенсі досягти того трансу, в який впадали учасники елевсінських містерій. Контроверзійні духовно-практичні експерименти студентів в якийсь момент спричиняють загибель випадкової людини, а потім призводять до розрахованого вбивства одного з учасників групи, який, на їхню думку, може розкрити таємницю.

Краса античності, знаменитий давньогрецький калакагатос як неподільна єдність істини, добра й краси в романі несподівано обертаються інтенціями страху й уседозволеності, розгортанням низки амбівалентних мотивів: «краса небезпечна», «краса жахлива»; «мораль відносна», «добро невіддільне від зла». Наративну стратегія твору визначає, по-перше, ретроспективна «Я-розповідь» (у момент події розповідання нараторові Річардові Пейпенові двадцять вісім років, а події розповіді відбуваються дев'ятьма роками раніше), а, по-друге, те, що у ньому з самого початку розкривається, хто $i$ як убив. Відтак центральним стає питання «чому», у пошуки відповіді на яке підключається не лише античність як така, а й різні аспекти ії спадщини в європейській культурі, включно, скажімо, з Достоєвським (порівн. слова наратора: «It was I killed the old pawnbroker woman and her sister Lizaveta with an axe and robbed them...» [12]).

Таким чином, у романі Донни Тартт античність постає амбівалентним феноменом, долучення до якої само по собі не гарантує формування моральноетичного стрижня людини, а навпаки потребує глибокого усвідомлення меж i критеріїв пізнання «таїни буття», проникнення у «серце пітьми», що постає одночасно і як «пітьма людського серця».

Виразним об'єднуючим чинником типологічних подібностей між згаданими романами $є$ те, що вони належать постмодерній добі й позначені впливом іiі світоглядних концепцій. Звісно, ці твори не можна 3 однаковою певністю віднести до постмодерністської парадигми, однак для більшості

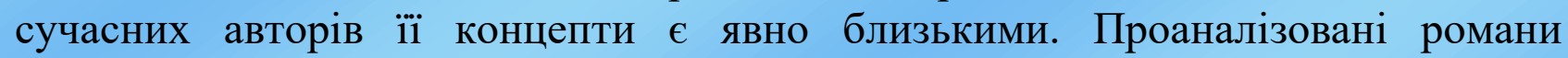
пронизують мотиви відносності людського знання й пізнання самої людини, плюральності істини, фундаментальний сумнів у причинно-наслідкових, прогресистських закономірностях еволюції людства. Якщо Ф. Рот досліджує невидимі й незбагненні коловороти долі, іiі невідворотність, навіть попри 
позірну перемогу індивідуума над нею, то Д. Тартт акцентує на небезпеках проникнення в ірраціональну природу людського єства. Дж. Кутсі найбільше цікавлять закладені в античній естетиці співвідношення раціонального й ірраціонального, неоднозначні взаємини мистецтва i дійсності, амбівалентна сутність художньої творчості й природи митця, основне призначення якого бути «секретарем невидимого» й вічно страждати через обмеженість можливостей розповісти «правдиву історію». Натомість Дж. Вінтерсон і М. Етвуд «переписують» античність крізь призму сучасних гендерних концепцій, деконструюють жорстку патріархальність й маскулінність античності, водночас універсалізуючи крізь призму фемінного екзистенціального досвіду концепти долі, обов'язку, відповідальності, вибору і свободи.

Отже, для сучасного англійськомовного роману в різних його національних варіантах характерна пильна увага й глибинне проникнення в античну добу з урахуванням колосального досвіду наукового й художньо-естетичного осмислення даного феномену. Це справді складний і багатоплановий дискурс, позначений амбівалентністю як власне рецепції античної спадщини, так і її ролі в осягненні суперечливих тенденцій сучасного людського буття.

\section{ЛІТЕРАТУРА}

1. Atwood M. The Penelopiad: The Myth of Penelope and Odysseus. URL: http://flibusta.is/b/180360/read (дата звернення: 08.02.2020).

2. Coetzee J. M. Elizabeth Costello. URL: https://ru.scribd.com/doc/312854475/6-CoetzeeElizabeth-Costello-Full-text-pdf (дата звернення: 10.02.2020).

3. Дилите Д. Античная литература. Москва : Греко-латинский кабинет Ю. А. Шичалина, 2003. $487 \mathrm{c}$.

4. Грабарь-Пассек М. Е. Античные сюжеты и формы в западноевропейской литературе. Москва : Наука, 1966. 320 с.

5. Грейвс Р. Мифы Древней Греции. Москва : Иностранка, Азбука-Аттикус, 2014. 832 с.

6. Head, D. The Cambridge Introduction to J. M. Coetzee. Cambridge U.P., 2009. 130 p.

7. Лифинцева Т. П. Образ Диониса в философии Ницше: трагедия мыслителя. История философии. 2001. Вып. 8. С. 47-57.

8. Мелетинский Е. М. Поэтика мифа. Москва : Наука, 1976. 407 с.

9. Поліщук Я. Поліфункціональність міфу в поетиці модернізму. Слово і Час. 2001. № 2. C. $35-45$.

10. Roth Ph. The Human Stain. URL: http://flibusta.is/b/215222/read (дата звернення: 25.01.2020).

11. Showalter E. Inventing herself: claiming a feminist intellectual heritage. New York : Scribner, 2001

12. Tartt D. The Secret History. URL: http://flibusta.is/b/129306/read (дата звернення: 29.01.2020).

13. The Penelopiad by M. Atwood. URL: https://en.wikipedia.org/wiki/The_Penelopiad (дата звернення: 30.01.2020).

14. Tóibín C. Why I left Ireland for Ancient Greece. URL: https://www.penguin.co.uk/articles/2017/colm-toibin--why-i-left-ireland-for-ancient-greece.html (дата звернення: 05.02.2020).

15. Tóibín C. House of Names. London : Penguin Random House, 2017. 272 p.

16. Winterson J. Weight. The Myth of Atlas and Heracles. URL: https://epdf.pub/weight-the-mythof-atlas-and-heracles.html (дата звернення: 08.02.2020). 


\section{REFERENCES}

1. Atwood, M. (2005), The Penelopiad: The Myth of Penelope and Odysseus, available at: http://flibusta.is/b/180360/read (in English).

2. Coetzee, J.M. (2003), Elizabeth Costello, available at: https://ru.scribd.com/doc/312854475/6Coetzee-Elizabeth-Costello-Full-text-pdf (in English).

3. Dilite, D. (2003), Ancient literature [Antichnaya Literatura], Greko-Latinskiy cabinet Yu.A. Shichalina, Moscow, 487 p. (in Russian).

4. Grabar-Passek, M. (1966), Antique Plots and Forms in Western European Literature [Antichnye s'uzhety i formy v zapadnoevropeiskoi literature], Nauka, Moscow, 320 p. (in Russian).

5. Graves, R. (2014), The Greek Myths [Mify Drevney Grecii], Inostranka, Azbuka-Attikus, Moscow, 832 p. (in Russian).

6. Head, D. (2009), The Cambridge Introduction to J. M. Coetzee, Cambridge U.P., 130 p. (in English).

7. Lifintseva, T. (2001), "The image of Dionysus in Nietzsche's philosophy: the tragedy of the thinker" [Obraz Dionisa v filosofii Nitschshe: tragediia myslitelia "], Istoria filosofii, Issue 8, pp. 47-57. (in Russian).

8. Meletinsky, Ye. (1976), The Poetics of Myth [Poetika mifa], Nauka, Moscow, 407 p. (in Russian).

9. Polishchuk, Ya. (2001), "Polyfunctionality in the poetics of modernism" ["Polifuncionalnist' mifu v poetyci modernizmu"], Slovo i Chas, No. 2, pp. 35-45. (in Ukrainian).

10. Roth, Ph. (2000), The Human Stain, available at: http://flibusta.is/b/215222/read (in English).

11. Showalter, E. (2001), Inventing herself: claiming a feminist intellectual heritage, Scribner, New York, 384 p. (in English).

12. Tartt, D. (1992), The Secret History, available at: http://flibusta.is/b/129306/read (in English).

13. The Penelopiad by M. Atwood (2020), available at: https://en.wikipedia.org/wiki/The Penelopiad (in English).

14. Tóibín, C. (2017), "Why I left Ireland for Ancient Greece", available at: https://www.penguin.co.uk/articles/2017/colm-toibin--why-i-left-ireland-for-ancient-greece.html (in English).

15. Tóibín, C. (2017), House of Names, Penguin Random House, London, 272 p. (in English).

16. Winterson, J. (2005), Weight. The Myth of Atlas and Heracles, available at: https://epdf.pub/weight-the-myth-of-atlas-and-heracles.html. (in English). 